\title{
ДЕРЖАВНА ПОЛІТИКА У СФЕРІ ПОДОЛАННЯ ТА ПРОТИДІЇ НАСИЛЬСТВУ В СІМ'Ї: ДОСВІД УКРАЇНИ ТА ІЗРАЇЛЮ
}

Сургова С.Ю., канд. пед. наук, доцент, Інститут державного управління, Чорноморський національний університет імені Петра Могили, м. Миколаїв, Україна.

Файчук О.Л., канд. пед. наук, доцент б.в.з., Інститут державного управління, Чорноморський національний університет імені Петра Могили, м. Миколаїв, Україна.

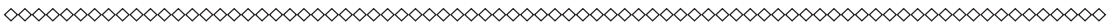

У статті проаналізовано ефективність держаної політики у сфері подолання та протидії насильству в сім'ї на прикладі країн Украӥнита Ізраїлю. Досліджено нормативно-правову базу захисту від насильства в сім '̈̈ в Украӥні та Ізрайлі, розглянуто устрій установ державного апарату зазначених країн, щзо забезпечують подолання та протидію насиллю в сім'ї. В основу методології дослідження покладено принциип пріоритету загальнолюдських иінностей. У складі інструментарію запропонованої статті застосовано синтез, порівняння, систематизація даних для теоретичного обтрунтування зазначеної дослідниками проблеми. Автори дійшли висновку, щзо приклад роботи по запобіганню $i$ профілактичі сімейного насильства в Ізраӥлі відрізняється своєю системністю, орієнтованістю на людину $i$ високою мірою соціальності. Він може бути покладений за основу організації відповідних установ в Украӥні, яка може ефективно вивчити $і$ перейняти, звичайно адаптувавши під власні обставини і иілі.

Ключові слова: насильство, державна політика, установи державного апарату, щчо забезпечують подолання та протидї насилля в сім'ях, законодавча база, сочіально- психологічна терапія. 
Постановка проблеми у загальному вигляді. Протягом тривалого періоду часу проблема насильства в сім’ї залишалася поза сферою правового регулювання та була захищена різноманітними звичаями та традиціями. Адже втручання в родині відносини зі сторони держави сприймалось суспільством як порушення таємниці приватного життя та засуджувалось. Все це спричинило зростання чисельності жертв сімейного насилля, перетворення його в латентні правопорушення, які залишалися поза увагою компетентних органів державної влади. Лише завдяки активним діям міжнародного руху з захисту прав жінок проблема сімейного насилля стала обговорюватись відкрито та почали розроблятись державні правові механізми протидії та подолання насилля в сім’ї. У зв’язку з тим, що саме жінки становили найбільш уразливу та незахищену групу жертв домашнього насилля з боку чоловіків (будь-то батько, чоловік, брат тощо) на початковому етапі запобігання насильству в сім'ї увійшло в поле зору світової спільноти як складова подолання насильства щодо жінок загалом $[18$, c. 11]. Проте сьогодні об' єктом насильницьких дій може стати будь-хто, що підтверджено статистичними даними.

Актуальність дослідження досвіду державної політики протидії та подолання насилля в сім’ї обумовлена небезпечністю проявів насильства і жорстокості в родині, які не лише негативно впливають на характер сімейних відносин та можливість виконання функцій сім'єю, а й стають вагомою запорукою розвитку злочинності в суспільстві загалом. Особлива небезпека окресленої проблеми полягає в тому, що вона стосується дітей, які можуть страждати від проявів різних видів насилля по відношенню до них, бути свідками насилля у своїй сім’ї, а у майбутньому - перенести отриманий негативний досвід у власні родини. Статистика 3 випадків сімейного насильства ставить уряди більшості країн світу перед необхідністю боротися з проблемою домашнього насильства. Для України особливо цінним є досвід інших країн у цьому напрямку, особливо Ізраїлю, що вважається сьогодні «державою загального благоденства» та має значний досвід у реалізації державної політики протидії та подолання насилля в сім’ї. 
Аналіз останніх досліджень і публікацій. Аналіз наукової літератури дозволив констатувати, що різні аспекти проблеми почали активно досліджуватися у другій половині XX ст., зокрема: Б. Леві визначав сімейне насильство як суспільну проблему; К. Шьортен займався описанням суб' єкту домашнього насильства; Л. Шерман і Б. Берк займались пошуком шляхів уникнення сімейного насильства; Ф. Аббасов, Г. Мошак, Д. Рівман розглядали юридичні наслідки насилля між подружжям; Ю. М. Антонян, С. Іншаков, Е. Побігайло, Р. Паркер і Д. Андерсон-Фасіл, Д. Белл. М. Гуліна, О. Шерман та багато інших вчених присвятили дослідження причинам і наслідкам сімейного насильства, а також особливості надання допомоги жертвам сімейного насильства. Отже, актуальність проблеми зумовили напрям проблеми яку досліджено в статті.

Формулювання цілей статті (постановка завдання). Мета статті - проаналізувати ефективність державної політики у сфері подолання та протидії насильству в сім’ї на прикладі України та Ізраїлю.

Виклад основного матеріалу дослідження. Досліджуючи науково-теоретичну базу, 3'ясували що уряди багатьох країн, демонструють активну позицію з подолання та протидії насильства в сім'ї. До 90-х років минулого століття уряди більшості країн світу визнали домашнє насильство серйозною соціальною проблемою та почали шукати шляхи iї розв'язання. Ці пошуки відбилися у низці міжнародних документів ООН, що дають означення терміну «насильство» і передбачають міжнародні механізми боротьби 3 насильством щодо жінок та домашнім насильством в цілому [6].

Так, згідно акту «Про захист від насильства в сім’ї» в Австрії потерпілий від домашнього насилля має право на захист від кривдника у його/їі життєвому середовищі і в соціальному оточенні. Цей акт надає поліції повноваження виселяти правопорушників i накладати заборонні ордери. Крім того у всіх дев'ятьох австрійських провінціях були засновані так звані «центри невтручання». Це неурядові організації, які фінансуються Федеральними міністерствами внутрішніх i соціальних справ. Їх основними завданнями $\epsilon$ : «турбота про людей, що зазнають насильства, i 
налагодження контактів 3 усіма інституціями, які займаються захистом від насильства. Поліція має без затримки повідомляти центрові втручання про кожне виселення i заборонний ордер, долучаючи також особисту інформацію потерпілої особи» [18, с.42].

Ми з'ясували, що проблема домашнього насильства $\epsilon$ актуальною і для Франції. Аналіз нормативно-правових актів, що прийняті у цій країні показав, що згідно чинного законодавства i міжнародних правових норм, скоєння злочинів подружжям i партнерами одне до одного є обтяжуючими обставинами і карається суворіше, ніж аналогічні злочини, скоєні не у відношенні до членів сім’̈. Відповідними правопорушеннями $\epsilon$, насамперед, «акти насильства - тортури і жорстокість, насильство, яке ненавмисно призвело до смерті, насильство, результатом якого є каліцтво чи повна непрацездатність, чи насильство, що призвело до непрацездатності, яка триває більше восьми днів, непрацездатності, що триває менше восьми днів чи що не приводить до непрацездатності» [18, с.46].

У відповідності 3 Кримінальним кодексом Норвегіï будьяка особа, яка шляхом погроз, примусу, позбавлення свободи, насильства чи будь-яких інших правопорушень протиправно або повторно жорстоко поводиться 3 його чи іï колишнім чи нинішнім подружжям, його чи їі колишнім чи нинішнім родичем подружжя по прямій лінії, його чи їі родичем по прямій лінії, будь-якою особою у його чи їі домі, або будь-якою особою, якою він чи вона опікується, підлягає ув'язненню на термін, що не перевищує три роки [18, с.48].

Основними підходами в політиці США щодо реагування на насильство в сім’ї $\epsilon$ контроль, який забезпечує стратегію обов’язкового реагування. «Контроль» як підхід до реагування на насильство в сім’ї полягає в жорсткому використанні інституційних ресурсів для зниження рівня насильства в сім’і, покарання тих, хто його вчиняє. Контроль, головним чином, виявляється у формі практики обов'язкового реагування на насильство в сім’ї, а саме: обов'язковий арешт, принцип обов'язкового судового провадження та обов'язкове інформування [18, с. 37-41].

Щодо Ізраїлю, який був, згідно аналізу літературних джерел, однією 3 перших країн, де було прийнято закон про заборону 
застосування фізичного насильства до жінки у 1977 році. I з тієї пори було досягнуто значного прогресу на цьому поприщі. Але, як і в усьому світі, проблема сімейного насильства i боротьби 3 ним лишається в Ізраїлі актуальною. Цьому сприяє декілька специфічних факторів. Наприклад, правовому суспільству Ізраїлю сусідствують чималі ісламістська іудейська спільноти, що підкоряються в плані сімейного побуту лише власним релігійним установам. За словами голови парламентської комісії з підтримки статусу жінки А. Лаві, що стосується арабського сектору, а також спільнот фалашів і фалашмура - ефіопських євреїв, - у цих шарах суспільства жінка, особливо молода, в разі найменшої неслухняності може бути піддана жорстокому насильству з боку старших членів родини [4]. Немало в цьому відношенні проблем і серед емігрантів з країн СНД.

Проблема домашнього насильства гостро торкається i України, де жінки, діти й люди похилого віку страждають від домашнього насильства набагато частіше, ніж можна собі уявити. На думку експертів, загальна кількість злочинів і адміністративних правопорушень, пов'язаних з насильством у сім’ї, $є$ більшою, ніж усі інші злочини взагалі. Президент міжнародного жіночого правозахисного центру «Ла Страда - Україна» К. Левченко повідомляє, що три мільйони дітей, які страждають від домашнього насильства, будучи свідками - це не статистичні дані, а соціологічні. Насправді таких дітей та дорослих значно більше, ніж звернень, зареєстрованих Національною поліцією України [2].

За офіційними даними, поліція за рік в Україні реєструє понад 100 тисяч звернень за фактом насильства в сім’і. Так у 2016 році було зареєстровано близько 120 тисяч звертань, у 2017 - 110 тисяч при цьому загинуло біля 600 жінок. Але до правоохоронців звертаються не більш ніж 10\% постраждалих від насильства [2].

За даними Міністерства соціальної політики України кожна 5-та жінка стає жертвою домашнього насильства, а протягом 2019 року зафіксовано понад 130 тис звернень громадян 3 приводу домашнього насильства, що на $15 \%$ більше у порівнянні 3 аналогічним періодом минулого року, з них 88 \% - від жінок, 10 
\% - від чоловіків. Від дітей надійшло 1055 звернень [12]. Загалом щороку через насильство у світі помирають 1,4 мільйона людей, лише 52\% жінок у світі, які перебувають у шлюбі або стосунках, можуть самостійно вирішувати, чи матимуть сексуальний контакт та чи користуватимуться контрацептивами [3].

Особливо негативно на динаміку розповсюдження насильства в сім’ї вплинула пандемія COVID-19. У світі з березня фіксують помітне збільшення кількості домашнього насильства в середньому на 25 - 30\% (у країнах ЄС, США, Малій Азії, Австралії та Африці). Одна $з$ найбільших організацій у Великій Британії, що займається питаннями домашнього насильства - Refuge - повідомила про зростання на 700\% звернень про допомогу до них, тоді як урядові «гарячі лінії» отримували лише на 20\% більше дзвінків із початку пандемії.

Міністерство внутрішніх справ України заявило, що збільшення звернень про домашнє насильство у зв'язку з карантином немає. А ось Громадська організація «Ла Страда Україна» зафіксувала суттєве зростання на свою «гарячу лінію». У березні провели 6800 консультацій, тоді як у січні та лютому їх кількість була в межах 1600. Найчастіше звертаються за допомогою жінки $(86,6 \%)$ та діти щодо жорстокого поводження з ними [9].

В Ізраїлі теж невтішна статистика щодо насилля в сім'і: за даними громадських організацій від насилля потерпає близько 100 тис. жінок та в двічі більше дітей. При цьому фіксуються всі види насилля: фізичне, економічне, психологічне та ін. У 2019 році в закладах для жінок, які постраждали від домашнього насилля перебували 641 жінка та 1047 дітей [4].

Очевидно, що така статистика потребує від держави реалізацію дієвих механізмів по більш ефективному вирішенню проблем сімейного насильства, в тому числі заходів з соціальної просвіти населення. Вдосконалення нормативно-правової бази, що не лише надійно захистила б жертв насильства, але й мала інструменти для корекційної роботи з особами, що його вчиняють. Вивчення того, як регламентовано і побудовано державний інститут соціальної допомоги наочно демонструє рівень розвитку суспільства країни і 
ефективність роботи в ній правозахисних організацій державного і недержавного характеру.

Заналізу нормативно-правової бази України видно, що діяльність щодо попередження насильства в сім'ї регламентується перш за все Конституцією України [7], Законами України «Про запобігання та протидію домашньому насильству» [17], «Про Національну поліцію» [15], «Про охорону дитинства» [16], та ще цілим рядом нормативних актів. Так, Закон України «Про попередження насильства в сім'ї» був прийнятий у результаті плідної співпраці народних депутатів 3 активістами жіночого та молодіжного руху держави 15 листопада 2001 року, він став першим у країнах СНД та Східної Свропи комплексним нормативним актом, спрямованим на запобігання цьому соціально негативному явищу. Також у 2017 році вийшов новий вдосконалений i перероблений у багатьох пунктах Закон України «Про запобігання та протидію домашньому насильству», що містить чіткі визначення, що саме вважається сімейним насильством, хто може стати його суб'єктами і об'єктами, які саме дії є проявами насильства фізичного, психологічного або економічного), а також надані ознаки насильства в сім’і. Зокрема, він поширює список осіб, чиї вчинки регламентуються даним документом. Цей Закон визначає організаційно-правові засади запобігання та протидії домашньому насильству, основні напрями реалізації державної політики у сфері запобігання та протидії домашньому насильству, спрямовані на захист прав та інтересів осіб, які постраждали від такого насильства [17].

На сьогоднішній день в Україні сімейне насильство підпадає під визначення домашнього насильства і розширює його. Відповідно до статті 1 Закону України «Про запобігання та протидію домашньому насильству», домашнє насильство визначається «як діяння (дії або бездіяльність) фізичного, сексуального, психологічного або економічного насильства, що вчиняються в сім'ї чи в межах місця проживання або між родичами, або між колишнім чи теперішнім подружжям, або між іншими особами, які спільно проживають (проживали) однією сім’єю, але не перебувають (не перебували) у родинних відносинах чи у шлюбі між собою, незалежно від того, 
чи проживає (проживала) особа, яка вчинила домашнє насильство, у тому самому місці, що й постраждала особа, а також погрози вчинення таких діянь» [17].

Діяння визнається насильством у сім’і лише тоді, коли воно порушує вимоги чинного законодавства та призводить чи може призводити до порушення конституційних прав і свобод члена сім'ї. Насильство в сім’ї може мати форму активних дій (нанесення побоїв, знищення майна тощо) або бездіяльності, тобто пасивної поведінки особи, коли вона не вчиняє дій, які могла та повинна була вчинити, щоб запобігти настанню шкідливих наслідків (наприклад, ненадання допомоги члену сім'ї, який перебуває в небезпечному для життя стані). За законодавством України насильством у сім’ї визнаються лише умисні діяння [17].

Відповідно до українського законодавства до органів та установ, на які покладається здійснення заходів 3 попередження насильства в сім’ї, відносить: спеціально уповноважений орган виконавчої влади 3 питань попередження насильства в сім’і, яким визначено Міністерство соціальної політики України, а також відповідні управління місцевих державних адміністрацій; відповідні підрозділи органів внутрішніх справ, до яких належать служба дільничних інспекторів поліції та кримінальна поліція у справах дітей органів внутрішніх справ; органи опіки і піклування; спеціалізовані установи для осіб, які вчинили насильство в сім'ї, та жертв такого насильства, до яких належать кризові центри для членів сімей, у яких вчинено насильство в сім'ї або існує реальна загроза його вчинення, центри медико-соціальної реабілітації жертв насильства в сім’ї [17].

Також до цього переліку органів додають: службу у справах дітей; центри соціальних служб для сім'ї, дітей та молоді; органи охорони здоров'я; органи освіти та установи кримінальновиконавчої системи (в частині попередження жорстокого поводження 3 дітьми).

У ході дослідження ми з'ясували, що законодавство в Ізраїлі у відношенні сімейного насильства є досить розвиненим. Основними нормативними актом, що регулюють цю проблему, є Закони «Про 
запобігання насильству в сім’ї» від 1991 року [11], «Про права осіб, які стали жертвами злочину», «Про захист населення від сексуального насилля», «Про попередження сексуальних домагань», «Про попередження загрозливої поведінки», «Про заборону торгівлі людьми» [13] також у 2020 році було прийнято законопроект про боротьбу з економічним насиллям [14].

Закони «Про запобігання насильству в сім'ї» був прийнятий 3 метою забезпечення 3 метою фізичного і правового захисту кожної людини, що страждає від тяжкого фізичного або духовного насильства, випадків знущання та сексуальної образи. У відповідності з даним Законом будь-який член родини, якому відомо про насилля в сім'ї або страждаючий від насилля, а також у випадку побоювання, що в сім’і може трапитись акт насильства, вправі діяти в одному з наступних напрямів: звернутися до соціальної служби, звернутися у поліцію або звернутися до суду з метою отримати судове розпорядження у відношенні запобігання насильству [11]. Закон також чітко визначає, хто вважається членом родини і на кого поширюються його вказівки (чоловік або жінка, батьки, чоловік або жінка одного з батьків, батько і мати чоловіка або жінки, дідусь і бабуся, нащадок або нащадок чоловіка або жінки, брат чи сестра, дядько або тітка, небіж або небога, шурин або невістка). Однак, Закон також затвердив, що особа, стверджена для піклування про неповнолітнього, безпомічного або об особі $з$ обмеженими можливостями, буде вважатися членом сім’ї.

3 метою запобігання насильству в сім’ї суд має право видати наказ про захист, тобто заборонити особі виконувати наступні дії цілком або частково, або обумовити їх: заходити до квартири, де проживає член його сім'ї або знаходитись на певній відстані від цієї квартири, навіть якщо вона має якісь права на цю квартиру; чіплятися до члена його сім’ї будь-яким чином, будь-де; діяти будь-яким чином, що перешкоджає або чинить перепони члену його сім'ї користуватися законним майном, навіть якщо в неї є якісь права на це майно.

Якщо судом видано наказ про захист стосовно особи, що має право володіння зброєю, суд за деякими винятками миттєво видає наказ про видалення зброї у такої особи. 
Окрім цього закону існує ще цілий ряд норм, що присвячені запобіганню насильства, наприклад, Карний закон передбачає спеціальні положення для «агресора» у сім’і - насильницькі злочини, скоєні у відношенні до членів родини вважаються більш тяжкими і тягнуть жорсткішу відповідальність [11].

Розглянувши законодавчу базу обох країн, слід також звернути увагу на устрій апарату установ, що забезпечують виконання цієї нормативної бази, попереджуючи і перешкоджаючи насильству в сім'ях, реалізуючи основні напрямки державної політики протидії та подолання насилля.

У Законі України «Про запобігання та протидію домашньому насильству» визначено основні напрямки державної політики у цій сфері: запобігання насильству, ефективне реагування та факти домашнього насильства, надання допомоги та захисту постраждалим від насильства, належне розслідування фактів насильства. Також визначено, що працівники кримінальної поліції у справах дітей тісно співпрацюють з органами виконавчої влади, службами у справах дітей, органами управління освітою та охорони здоров'я, органами прокуратури, центрами надання вторинної правової допомоги та іншими установами відповідно до законодавства. Крім цього існує мережа соціальних закладів, які надають допомогу постраждалим від домашнього насильства (центри соціальних служб для сім’і, дітей та молоді, притулки, територіальні центри соціального обслуговування (надання соціальних послуг), центри соціально-психологічної допомоги тощо) [17].

Розглянемо основні повноваження суб'єктів, що реалізують заходи державної політики у сфері подолання та протидії насильству в сім'ї:

- Органи Національної політики України: виявляють факти домашнього насильства, інформують постраждалих осіб про їх права, виносять термінові заборонні приписи стосовно кривдників, здійснюють контроль за виконання кривдниками заходів протидії насильству тощо;

- Служби у справах дітей: розробка заходів 3 захисту прав постраждалої дитини; прийом i розгляд заяв про домашнє 
насильство; інформування дітей та батьків про права та послуги; влаштування дитини в центр соціально-психологічної реабілітації чи в іншу установу для проживання та реабілітації постраждалої дитини; здійснення профілактичної роботи; взаємодія 3 іншими суб'єктами у сфері подолання та протидії домашньому насильству тощо,

- Центри соціальних служб для сім’ї, дітей та молоді: інформують постраждалих осіб про їх права та можливі соціальні послуги; відповідно до Порядку здійснення соціального інспектування центрами соціальних служб для сім'ї, дітей та молоді сімей і осіб, які опинилися у складних життєвих обставинах здійснюють соціальне інспектування сімей, де мають місце випадки вчинення насильства в сім'ї або в яких існує реальна загроза його вчинення; проводять оцінку потреб сімей та їх членів; надають послуги з соціального супроводу, консультування, соціальної профілактики, соціальної адаптації, кризового та екстреного втручання, посередництва тощо постраждалим від домашнього насильства особам;

- Органи опіки і піклування: вирішують питання щодо надання соціальних послуг постраждалій особі; влаштування постраждалої особи до закладу соціального захисту; порушення перед судом питання про звільнення в установленому законодавством порядку від повноважень опікуна або піклувальника у разі вчинення ними домашнього насильства стосовно недієздатної особи; захист прав постраждалої особи тощо;

- Центри соціально-психологічної допомоги особам, які постраждали від домашнього насильства: надає комплексну допомогу постраждалим особам, організовує та прожить групи взаємодопомоги, семінари та тренінги для постраждалих осіб; проводить інформаційну просвітницьку діяльність; здійснюють психологічну та роз'яснювальну роботу з постраждалими; сприяють наданню екстреної медичної допомоги тощо [10];

- Заклади освіти: проводять навчально-виховну роботу по запобіганню домашньому насильству, повідомляють органи Національної поліції про факти вчинення насильства, організовують роботу відповідних спеціалістів 3 постраждалими дітьми. 
- Заклади охорони здоров’я: повідомляють органи Національної поліції про факти насильства, забезпечують проведення медичного обстеження постраждалих осіб, надають медичну допомогу постраждалим та інформують їх про можливі соціальні послуги тощо.

В контексті нашого дослідження важливим є аналіз політики Ізраїлю 3 забезпечення соціального добробуту населення. Як відомо, вона $є$ однією $з$ найрозвиненіших у світі. I, виходячи 3 вищеозначених тенденцій, проблемі сімейного насильства приділяється активна увага з боку ізраїльської системи соціальної служби. В своїй соціальній політиці Ізраїль спирається на теорію «держави загального благоденства (добробуту)». Держава загального благоденства є терміном для усіх механізмів, що використовуються державою та спрямовані на перерозподіл ресурсів у суспільстві. Ці механізми збирають ресурси громадян - зазвичай у вигляді податків, але іноді і в інших формах, - і перерозподіляють їх. Загальними механізмами перерозподілу є системи державної освіти, охорони здоров'я, грошова допомога, державне житло, тощо.

За визначенням Д. Марша держава загального благоденства це «країна, у якій існує цілеспрямована політика, що забезпечує мінімальний рівень життя для усіх і максимально рівні можливості для кожного, щоб кожний міг досягти максимального рівня у своєму житті відповідно своїм талантам і здібностям» [8, с. 12]. Насильство в сім’і, в свою чергу, порушує право людини на рівний захист перед законом і відсутність дискримінації за статевою, віковою, сімейною або соціальною ознаками, право не зазнавати жорстокого ставлення, право на життя і фізичну безпеку, високий рівень психічного і фізичного здоров'я. Тож, державна політика 3 подолання і профілактики сімейного насильства в Ізраїлі спрямована на реалізацію рівних прав для будь-якої людини. Держава робить усе можливе і надає необхідну інформаційну і матеріальну підтримку людям, що зазнали сімейного насильства, щоб вони мали змогу залишити вороже середовище і бути у безпеці.

У Ізраїлі значно розвинений інститут соціального страхування, яким займається Міністерство соціального захисту і суспільних 
послуг, що спільно із міським муніципалітетом виконує нагляд, фінансування, співпрацю і супервізію Департаменту соціальної роботи.

Департамент соціальної роботи містить відділи і терапевтичні одиниці, що пов'язані з терапією і профілактикою насильства в сім'ї, до яких, в тому числі, належить центр терапії і запобігання сімейного насильства $[1$, с. 38$]$. Розглянемо діяльність цих установ більш детально.

Центр терапії і запобігання сімейному насильству, що діє згідно закону «Про запобігання сімейного насильства» і керується Міністерством соціальної роботи спільно з міським департаментом соціальної роботи, займається: діагностичною і консультаційною роботою; наданням необхідної інформації населенню в цілому і людям, що звертаються до центру; розробленням програм виходу i запобігання насильству (притулок для жінок і їх дітей, звертання в поліцію і суд, надання безкоштовної юридичної допомоги, звертання до Міністерства будівництва, матеріальна допомога на знімання житла); терапією для дітей, підлітків і дорослих (індивідуально, в парах або групах).

Запити до центру надходять поліції, служби корекції звільнених в'язнів, соціальних працівників в тюрмах, медичних закладах, по роботі з сім'ями і тих, що захищають інтереси дітей в процесі розлучення, а також 3 кризових центів «Діти в зоні ризику» $\mathrm{i}$ «24-7 Телефонна лінія». Центр терапії і запобігання сімейного насильства працює у взаємодії з фондами соціальної допомоги, терапевтичними центрами для жертв сексуального насильства, Міністерством будівництва і центром зайнятості [1, с.48-49].

Проаналізувавши досвід роботи цих установ, ми з'ясували, що висуваються високі професійно-етичні вимоги до терапевта, якій здійснює соціально-психологічний супровід (терапію) в умовах центру. Крім базового рівня освіти існує система постійного професійного i особистісного самовдосконалення працівників центру. Терапевти постійно підвищують кваліфікацію, як відвідуючи спеціальні курси, тренінги, особистісну терапію, так i самостійно слідкуючи за професійною літературою, дізнаючись 
про найновітніші розробки в галузі із професійних видань та досліджень сучасних вчених. Це дозволяє спеціалістам надавати клієнткам допомогу на найвищому професійному рівні. Важливою умовою професійного вдосконалення і розвитку сучасної науки $є$ також власна наукова діяльність терапевтів. В центрі відбуваються дослідження, розробка і впровадження нових або удосконаленних методів терапії. Соціальні працівники беруть участь у наукових конференціях по всьому світі, публікують роботи у періодичних виданнях, отримують нові кваліфікаційні ступені. Однією 3 професійних умов до роботи терапевтів в центрі $є$ супервізія, яку терапевти повинні проходити якнайменш кожного тижня. Дослідники в галузі психології та соціальної роботи визначають супервізію як насичену міжособову взаємодію, основна мета якої полягає в тому, щоб одна людина, супервізор, зустрілася з іншою, терапевтом, і спробувала зробити останню ефективнішою в допомозі людям. Супервізія є універсальною формою підтримки терапевтів, що дозволяє їм сфокусованим поглядом подивитися на свої труднощі в роботі з клієнтами, а також розділити частину відповідальності за цю роботу з іншим, як правило, досвідченішим професіоналом [63, c. 47]. На жаль в Україні ця практика не є разповсюдженною, не існує інституту супервізорства взагалі.

У ході нашого дослідження, ми з'ясували, що до обов'язків соціального працівника належить підтримка державної політики, що спрямована на видалення проявів нерівності або дискримінації за будь-якими уродженими ознаками у суспільстві, а також приймати активну участь в реалізації цієї політики. Цей принцип має особливу значущість у роботі центру терапії та запобігання сімейному насильству, бо цільовою групою нашої роботи є переважно жінки, що постраждали від насильницьких дій збоку чоловіків.

Таким чином, професійно етичні вимоги до працівників, що виконують соціально-психологічний супровід і терапію, є не лише переліком рекомендацій, але важливим документом, що регламентує усі сфери терапевтичної і навіть особистісної діяльності соціального працівника, а також особливим інструментом, що дозволяє ефективно регулювати відносини між терапевтом і 
клієнтом, терапевтом і колегами, терапевтом і суспільством, а також вирішувати професійні дилеми з точки зору професійної етики.

Аналіз існуючої моделі захисту дітей від насильства в Ізраїлі дав змогу прийти до висновку, що дитина стоїть у центрі уваги суспільства. Задоволення іiі потреб та збереження психічного i фізичного здоров'я стоять вище інтересів родини загалом. Для досягнення високих результатів у такій політиці держава здійснює пильний контроль за життям сім'ї та окремо батьків, приділяючи особливу увагу неповним родинам [5, с. 282].

Починаючи 5 років, дітям надають знання щодо їх прав, свобод та гарантій, передбачених законодавством. Наприклад, усі діти знають, що «їх тіло належить виключно їм», а тому батьки не мають права застосовувати фізичну силу як засіб виховання, нав'язувати зачіску, одяг та інше. Крім того, змалечку підростаюче покоління привчають, що про факт порушення прав терміново необхідно повідомити вихователю, який зобов'язаний проінформувати соціальні служби або поліцію у випадку наявних ознак насилля (синці та подряпини). У початковій школі дітям надають знання про психологічний тиск та психологічне насилля, застосування якого жорстоко карається. Якщо хтось із сусідів чи родичів повідомляє до поліції про факти фізичного чи психологічного насилля над дитиною, впродовж п’яти хвилин на місце виклику приїздить поліція в супроводі лікаря та/чи психолога. Спеціалісти здійснюють огляд потерпілого i, якщо виявляють сліди знущань, дитину вилучають 3 родини, у разі не підтвердження факту батькам виносять попередження та призначають спостереження за проблемною сім'єю соціальним працівником на термін від місяця до півроку.

З 1989 р. в Ізраїлі діє закон, який зобов'язує громадян інформувати соціальні служби або поліцію не просто про погане ставлення батьків до дитини, а навіть про підозру щодо цього. Щороку Міністерство соціального захисту отримує приблизно 30 тис. таких повідомлень, 40\% з яких є безпідставними [5, с. 283-284].

У школах, якщо дитину хтось ображає, вона зобов'язана повідомити про це вчителю, психологу, соціальному працівнику, 
охоронцю. В основі освітньої концепції стоїть теза: «Ніколи не знаєш, хто твій ворог, а тому краще звернись до фахівців, які спеціально навчені вирішувати такі проблеми». Так формується стиль життя всього суспільства, кожен має робити свою справу в умовах суспільного розподілу праці.

За умов повної відсутності насилля в сім’і у незначної кількості батьків виникають проблеми 3 вихованням своїх дітей, для таких педагогічно занедбаних дітей існують спеціалізовані інтернати, куди їх відправляють на тимчасове утримання з метою перевиховання (адаптації, реабілітації, інтеграції, ресоціалізації). Після проходження повного курсу під наглядом профільних спеціалістів дитина повертається батькам.

Непоодинокими є випадки, коли сім’ї з дітьми потрапляють у скрутну економічну ситуацію, тому створена і функціонує мережа інтернатів тимчасового утримання, куди дітей віддають з власної волі та в яких дитина гарантовано отримує харчування, одяг, допомогу педагогів, але може зустрічатись з батьками і навіть ночувати вдома. 3 таких закладів батьки мають право забирати дитину в будь-який час, не отримуючи на це дозволу від державних соціальних служб.

Висновки Проаналізувавши досвід державної політики щодо подолання та протидії насилля в сім’ї, ми дійшли висновку, що в Ізраїлі заходи державної політики торкається всіх верств населення i передбачує майже усі випадки як фізичного, так і психологічного пригнічення членів родини, що можуть трапитись. Ця система має чітко підпорядковану ієрархію і розвинену мережу відділів, що не лише займаються кожний своєю справою, але й знаходяться у взаємодії з метою запобігання та подолання негативних наслідків сімейного насильства.

Тож, приклад роботи по запобіганню і профілактиці сімейного насильства в Ізраїлі відрізняється своєю системністю, орієнтованістю на людину і високою мірою соціальності. Він може бути покладений за основу організації відповідних установ в Україні, яка може ефективно вивчити і перейняти, звичайно адаптувавши під власні обставини і цілі, досвід Ізраїлю - країни загального добробуту. Разом 3 тим слід підкреслити, що Україна досягла значного 
прогресу у формуванні законодавчої бази щодо питань запобігання сімейного насилля, використовуючи і адаптуючи під власні потреби досвід країн світу з розвиненим соціальним сектором, у тому числі Ізраїльську соціальну систему. I це $є$ великим кроком у формуванні правової держави. Але статистика зі скоєння насильства у родині $\epsilon$ досі невтішною. Тож на цьому поприщі необхідно вирішення багатьох проблем практичної організації роботи системи державних органів і закладів по боротьбі з сімейним насиллям.

Перспективи подальших наукових пошуків вбачаємо в аналізі світових інноваційних методів соціально-психологічної терапії 3 профілактики та подолання насилля в сім'ях, а також досвіду роботі установ державного апарату соціально розвинених країн, що забезпечують основні напрямки реалізації цієї політики.

\section{Стаття надійшла до редакції: 22.04.20}

\section{STATE POLICY IN THE FIELD OF OVERCOMING AND COUNTERING DOMESTIC VIOLENCE: THE EXPERIENCE OF UKRAINE AND ISRAEL}

Svitlana Surgova, $\mathrm{PhD}$ in Pedagogy, Associate professor Black Sea National University of Petro Mohyla Mykolaiv, Ukraine.

Olena Faichuk, $\mathrm{PhD}$ in Pedagogy, Associate professor Black Sea National University of Petro Mohyla Mykolaiv, Ukraine.

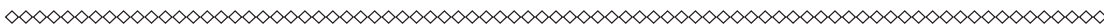

The article analyzes the effectiveness of state policy in overcoming and counteraction domestic violence on the example of the countries of UKRAINE AND ISRAEL. The normative-legal base of protection against domestic violence in Ukraine and Israel has been studied, the structure of the state apparatus of the mentioned countries, which provide overcoming and counteraction to domestic violence, has been considered. The research methodology is based on the principle of 
priority of universal values. As part of the toolkit of the proposed work used synthesis, comparison, systematization of data for the theoretical justification of the problem mentioned by researchers. An analysis of the current model of protecting children from violence in Israel has led to the conclusion that the child is the focus of society. Meeting child needs and maintaining child mental and physical health are above the interests of the family as a whole. In order to achieve high results in such a policy, the state exercises close control over the lives of the family and parents separately, paying special attention to single-parent families. After analyzing the experience of public policy in overcoming and countering domestic violence, the researchers concluded that in Israel, public policy measures affect all segments of the population and provide for almost all cases of physical and psychological oppression of family members that may occur. This system has a clearly subordinated hierarchy and a well-developed network of departments that not only do their job, but also interact to prevent and overcome the negative consequences of domestic violence. The authors emphasize that the example of work to prevent domestic violence in Israel is characterized by its systemic nature, human orientation and a high degree of sociality. It can be used as a basis for the organization of relevant institutions in Ukraine, which can effectively study and adopt, usually adapting to their own circumstances and goals. Researchers see prospects for further research in the analysis of the world's innovative methods of socio-psychological therapy for the prevention and overcoming of domestic violence, as well as the experience of state institutions of socially developed countries that provide the main directions of this policy.

Key words: violence, state policy, institutions of the state apparatus that provide overcoming and counteraction to domestic violence, legal framework, social and psychological therapy.

\section{Received: 22.04.20}




\section{References}

1. Aviram, U., Katan, J. (1991). Professional preferences of social workers: Prestige scales of populations, services and methods in social work. International social work, 3, 37-55 [in English].

2. Chernova, O. (2018). Miliony ditei v Ukraini shchoroku staiut svidkamy domashnoho nasylstva - pravozakhysnytsia [Millions of children in Ukraine witness domestic violence every year - a human rights activist]. Hromadske - Public. Retrieved from https://hromadske.ua/posts/protidiya-domashnomu-nasilstvu [in Ukrainian].

3. Domashnie nasylstvo: zhakhlyva statystyka ta alhorytm dii [Domestic violence: horrible statistics and algorithm of action] (2019). mayak.media. Retrieved from https://mayak.media/read/card/53287/domashne-nasilstvo-zhahliva-statistika-ta-algoritm-dii [in Ukrainian].

4. Gelman, Z. (2014). V masshtabah katastrofyi. Posle zayavleniya v politsiyu primirenie nevozmozhno [On the scale of a catastrophe. After reporting to the police, reconciliation is impossible]. Rossiyskaya gazeta-Federalnyiy vyipusk - Russian newspaper-Federal issue, 24. Retrieved from https:// rg.ru/2014/02/05/israil.html [in Russian].

5. Klymenko, O. Yu. (2016). Osoblyvosti instytutsionalizatsii sotsialnoho zakhystu ditei u kryzovykh sytuatsiiakh v suchasnomu ukrainskomu suspilstvi [Features of institutionalization of social protection of children in crisis situations in modern Ukrainian society]. Candidate's thesis - Candidate's theses. Kharkiv: Karazin KNU [in Ukranian].

6. Kochemyrovska, O., Streistianu, D., Khrystova, H. (2010). Efektyvne zapobihannia ta reahuvannia na vypadky nasylstva $\mathrm{v}$ simi [Effectively prevent and respond to domestic violence]. Zaporizhzhia: Drukarskyi svit [in Ukrainian].

7. Konstytutsiia Ukrainy [The Constitution of Ukraine] (1996). Vidomosti Verkhovnoi Rady Ukrainy - Information of the Verkhovna Rada of Ukraine, 30. Retrieved from http://zakon5.rada.gov.ua/laws/show/254\%D0\%BA/96$\% \mathrm{D} 0 \% \mathrm{~B} 2 \% \mathrm{D} 1 \% 80$ [in Ukrainian].

8. Marsh D., Stoker, G. (2010). Theory and methods in political science. Basingstoke: Palgrave Macmillan [in English].

9. Plaskon, Ye. (2020). COVID-19, domashnie nasylstvo ta potrebuiuchi: yak pidtrymuiut samotnikh materiv, litnikh liudei ta bezkhatkiv na Lvivshchyni [COVID-19, domestic violence and the needy: how to support single mothers, the elderly and the homeless in the Lviv region]. www.032.ua. Retrieved from 
https://www.032.ua/news/2765597/covid-19-domasne-nasilstvo-ta-potrebuuciak-pidtrimuut-samotnih-materiv-litnih-ludej-ta-bezhatkiv-na-lvivsini [in Ukrainian].

10. Postanova Kabinetu Ministriv Ukrainy «Pro zatverdzhennia typovykh polozhen pro dennyi tsentr sotsialno-psykholohichnoi dopomohy osobam, yaki postrazhdaly vid domashnoho nasylstva ta/abo nasylstva za oznakoiu statti, ta spetsializovanu sluzhbu pervynnoho sotsialno-psykholohichnoho konsultuvannia osib, yaki postrazhdaly vid domashnoho nasylstva ta/abo nasylstva za oznakoiu statti» [Resolution of the Cabinet of Ministers of Ukraine «On approval of standard provisions on the day center of social and psychological assistance to victims of domestic violence and / or violence on the basis of the article and specialized service of primary social and psychological counseling of victims of domestic violence and / or violence for article tag»] (2019). zakon.rada.gov.ua. Retrieved from https://zakon.rada.gov.ua/laws/show/824-2019-\%D0\%BF\#Text [in Ukrainian].

11. Prevention of Family Violence Law (1991). www.icj.org. Retrieved from https://www.icj.org/wp-content/uploads/2013/05/Israel-Prevention-ofFamily-Violence-Law-5751-1991-eng.pdf [in English].

12. Sokolovska, Yu. (2020). Kozhna 5 zhinka v Ukraini stykaietsia z tiieiu chy inshoiu formoiu nasylstva [Every 5th woman in Ukraine faces some form of violence]. www.msp.gov.ua. Retrieved from https://www.msp.gov.ua/ news/18311.html [in Ukrainian].

13. Svid, V., Landver, S., Gamliel, G. (2011). Nikto ne smeet prichinyat vam vred [No one dares to harm you]. archive.moia.gov.il. Retrieved from http://archive.moia.gov.il/Publications/NoHarm_ru.pdf [in Russian].

14. V Izraile primut zakon protiv ekonomicheskogo nasiliya $\mathrm{V}$ seme [Israel will pass a law against economic violence in the family] (2020). www.vesty. co.il. Retrieved from https://www.vesty.co.il/article/HkR2JCZID [in Russian].

15. Zakon Ukrainy «Pro Natsionalnu politsiiu» [Law of Ukraine «On the National Police»] (2015). Vidomosti Verkhovnoi Rady Ukrainy - Information of the Verkhovna Rada of Ukraine, 40-41. Retrieved from http://zakon.rada.gov. ua/laws/show/580-19 [in Ukrainian].

16. Zakon Ukrainy «Pro okhoronu dytynstva» [Law of Ukraine «On Child Protection»] (2001). Vidomosti Verkhovnoi Rady Ukrainy - Information of the Verkhovna Rada of Ukraine, 30. Retrieved from https://zakon.rada.gov.ua/ laws/show/2402-14\#Text [in Ukrainian].

17. Zakon Ukrainy. «Pro zapobihannia ta protydiiu domashnomu nasylstvu» [Law of Ukraine. "On Prevention and Counteraction to Domestic Vio- 
lence"] (2018). Vidomosti Verkhovnoi Rady Ukrainy - Information of the Verkhovna Rada of Ukraine, 5. Retrieved from https://zakon.rada.gov.ua/laws/ show/2229-19\#Text [in Ukrainian].

18. Zaporozhtsev, A.V., Labun, A.V., Zabroda, D.H., Basysta, I.V., Drozdova, I.V., Bryzhyk, V.O., Musiienko, O.M (2012). Nasylstvo v simi ta diialnist orhaniv vnutrishnikh sprav shchodo yoho podolannia [Domestic violence and law enforcement]. Kyiv [in Ukrainian].

\section{Відомості про авторів / Information about the Authors}

Сургова Світлана Юріївна: Чорноморський національний університет імені Петра Могили вул. 68 Десантників 10, Миколаїв, 54003, Україна.

Svitlana Surgova: Black Sea National University of Petro Mohyla: 68 Desantnykiv str. 10, Mykolaiv, 54003, Ukraine.

\section{ORCID.ORG/ 0000-0002-3840-2924}

\section{E-mail: surgova.svetlana@gmail.com}

Файчук Олена Леонідівна: Чорноморський національний університет імені Петра Могили вул. 68 Десантників 10, Миколаїв, 54003, Україна.

Olena Faichuk: Black Sea National University of Petro Mohyla: 68 Desantnykiv str. 10, Mykolaiv, 54003, Ukraine.

ORCID.ORG/ 0000-0002-6663-3287

E-mail: e.l.fajchuk@ukr.net 